\author{
AMERICAN JOURNAL OF FOOD AND NUTRITION \\ Print: ISSN 2157-0167, Online: ISSN 2157-1317, doi:10.5251/ajfn.2011.1.4.178.184 \\ (C) 2011, ScienceHuß, http://www.scihub.org/AJFN
}

\title{
Medicinal plant knowledge of ethnic groups in Douala town, Cameroon Mpondo Mpondo Emmanuel ${ }^{1,2^{*}}$ and Dibong Siegfried Didier ${ }^{1,3}$ \\ ${ }^{1}$ Department of Pharmaceutical Sciences, Faculty of Medicine and Pharmaceutical Sciences, P.O. Box 2701, University of Douala, Cameroon \\ ${ }^{2}$ Department of Biochemistry, Faculty of Science, P.O. Box 24157, University of Douala, Cameroon \\ ${ }^{3}$ Department of Botany, Faculty of Science, P.O. Box 24157, University of Douala, Cameroun
}

\begin{abstract}
Plants have traditionally been used as a source of medicine in Cameroon since early times for the control of various ailments afflicting humans and their domestic animals. However, little work has been made in the past to properly document and promote the knowledge. Today medicinal plants and the associated knowledge in the country are threatened due to deforestation, environmental degradation and acculturation. Urgent ethnobotanical studies and subsequent conservation measures are, therefore, required to salvage these resources from further loss. The purpose of the present study was to record and analyse traditional medicinal plant knowledge of ethnic groups in Douala town, Cameroon. Semi-structured interviews were conducted with informants of 75 households selected during transect walks made to houses as well as those identified as knowledgeable and elders to gather data regarding local names of medicinal plants used, parts harvested, ailments treated, remedy preparation methods, administration routes, dosage and side effects. Purposive sampling method was used in the selection of study sites within the study region. The study revealed 94 medicinal plants that belonged to 46 families and 84 genera. The majority of medicinal plants were herbs and leaf was the most frequently used part in the preparation of remedies. Significantly higher average number of medicinal plants was claimed by men, older people and illiterate ones as compared to women, younger people and literate ones, respectively. The majority of the medicinal plants used in the study area were uncultivated ones. The study revealed acculturation as the major threat to the continuation of the traditional medical practice in the study area. Awareness should, therefore, be created among the ethnic groups, especially the young ones, by concerned organizations and individuals regarding the usefulness of the practice.
\end{abstract}

Key words: Plants, knowledge, ailments, Ethnic groups, Douala

\section{INTRODUCTION}

Ethnobotanical knowledge is common and important among the tribal communities. But little effort has so far been made to document medicinal plants and the associated knowledge despite ongoing deforestation, environmental degradation and acculturation in the country. However, there is a need for immediate ethnobotanical surveys to save medicinal plants and the associated knowledge from further loss. A number of ethnic communities residing in the study area are partially or fully dependent on the forest resources to meet their requirements. Plants have traditionally been used as a source of medicine in Cameroon since early times for the control of various ailments afflicting humans and their domestic animals
(Betti and Lejoly, 2000; Guedje and Fankap, 2001; Betti, 2002; Guedje, 2002; Guedje et al., 2003, 2008; Jiofack et al., 2010; Dibong et al., 2011a,b,c,d; Din et al., 2011; Priso et al., 2011).

The purpose of this ethnobotanical study was to document and analyze medicinal plant knowledge of ethnic groups in Douala town, Cameroon.

\section{MATERIALS AND METHODS}

Description of the study area: Cameroon is a multiethnic and multilingual country. There are more than ten different ethnic groups in Douala. Douala town lies between $03^{\circ} 40^{\prime}-04^{\circ} 11^{\prime} \mathrm{N}$ latitude, $09^{\circ} 16^{\prime}$ $09^{\circ} 52^{\prime} \mathrm{E}$ longitude. The height ranges from $13 \mathrm{~m}$. The city has a climate that belongs to equatorial area 
said Cameroonian characterized by two seasons with a long rainy season (at least 9 months), heavy rainfall (about $4000 \mathrm{~mm}$ per year), high temperatures (26.7 ${ }^{\circ} \mathrm{C}$ ) and stable. The average minimum temperature in Douala to 30 years $(1961-1990)$ is $22.6{ }^{\circ} \mathrm{C}$ in July and the average maximum temperature is $32.3^{\circ} \mathrm{C}$ in February. The relative humidity of the air remains high through out the year and close to $100 \%$ (Din et al., 2008). It has been found that various traditional knowledge systems are being practiced and followed by since long by the inhabitants of different areas of Douala town (Fig.1).
Methodology: The present study was conducted during 2009 to 2010 covering different village development families of the Douala region. During the 75 households visits, ethnobotanical information was gathered through oral interviews and discussion with knowledgeable persons of the ethnic communities. Voucher specimens were collected from the field during the flowering and fruiting periods. While noting ethnobotanical information, every care was taken to record the local names of the plants, parts used, method of drug preparation and

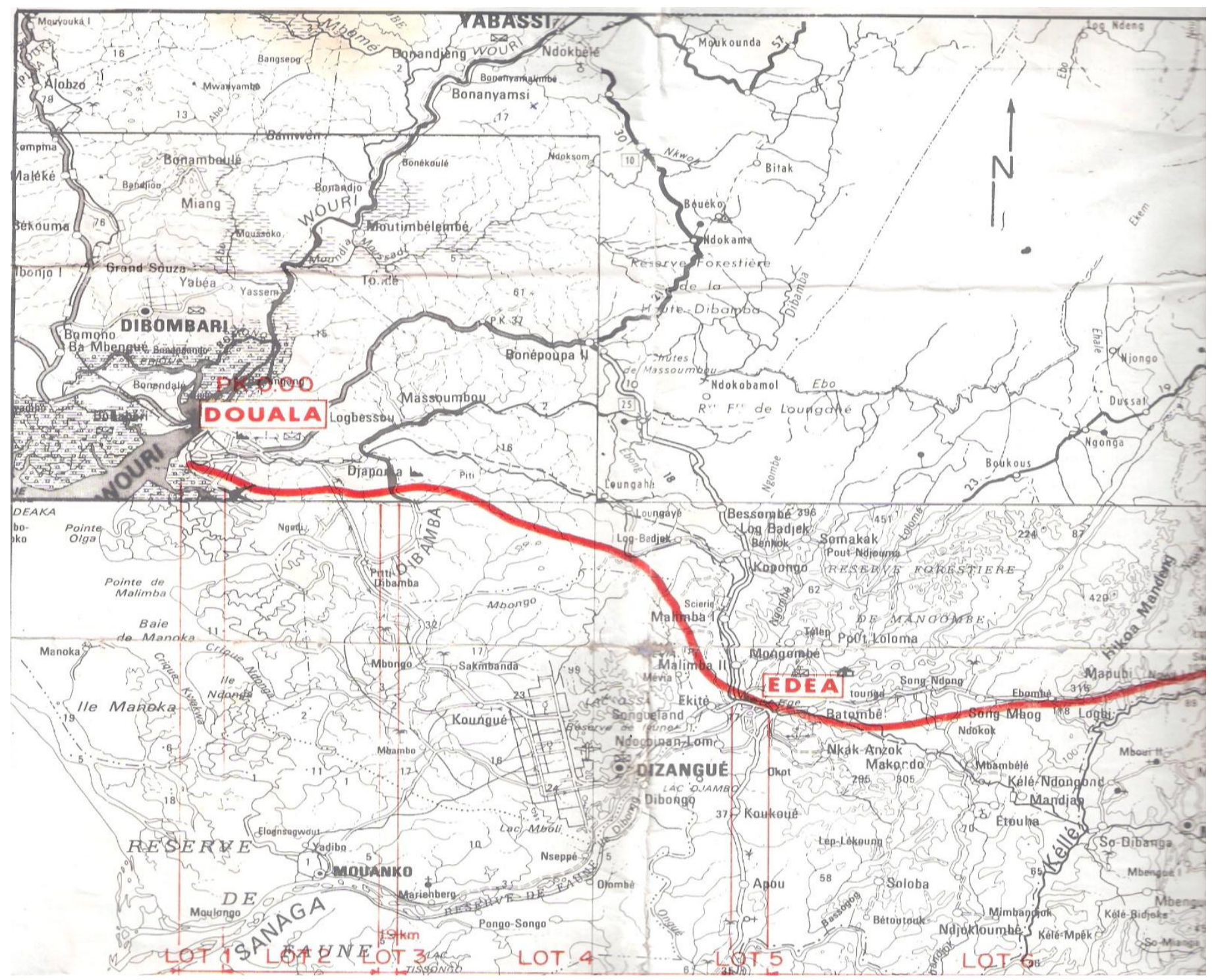

Fig. 1 Localization of Douala town. 
dosage uses. The specimens were also identified with the help of local floras (Letouzey, 1968; Tongo and Ekwalla, 2003). Herbarium specimens will be lodged in the Department of Pharmaceutical Sciences, University of Douala.

\section{RESULTS}

The study revealed 94 medicinal plant species that belonged to 46 families and 84 genera (Table 1). The most dominant families in the study were Fabaceae (10 species); Arecaceae and Poaceae (9 species); Solanaceae (7 $\quad$ species); Anacardiaceae, Cucurbitaceae, Euphorbiaceae and Rubiaceae (3 species). Other families with low number are list below: Apocynaceae, Araceae, Liliaceae, Malvaceae, Musaceae, and Sterculiaceae (2 species). Other families are represented by only one species (Table 1).

Table 1. Medicinal plants cited by the ehtnic groups of Douala town.

\begin{tabular}{|c|c|c|c|}
\hline Scientific names & Families & Common names & Citations \\
\hline Allium cepa L. & Liliaceae & Oignon & 29 \\
\hline Psidium guajava L. & Myrtaceae & Goyavier & 29 \\
\hline Carica papaya L. & Caricaceae & Papayer & 26 \\
\hline Mangifera indica $L$. & Anarcadiaceae & Manguier & 26 \\
\hline Cymbopogon citratus (D.C) Stapf & Poaceae & Citronnelle & 24 \\
\hline Vernonia amygdalina Del. & Asteraceae & Ndolè & 19 \\
\hline Zingiber officinalis Rosc. & Poaceae & Gingembre & 18 \\
\hline Cola acuminata Schott & Sterculiaceae & Colatier & 15 \\
\hline Musa sapientum L. & Musaceae & Bananier & 15 \\
\hline Adansonia digitata $\mathrm{L}$. & Bombacaceae & Baobab & 14 \\
\hline Capsicum frutescens $\mathrm{L}$. & Solanaceae & Piment & 13 \\
\hline Persea americana Mill. & Lauraceae & Avocatier & 13 \\
\hline Aloe vera (L.) Burm. F. & Agavaceae & Aloe vera & 12 \\
\hline Ananas comosus Merr. & Bromeliaceae & Ananas & 12 \\
\hline Citrus limon $\mathrm{L}$. & Rutaceae & Citronnier & 11 \\
\hline Allium sativum $\mathrm{L}$. & Liliaceae & Ail & 10 \\
\hline Brassica oleracea L. & Brassicaceae & Choux & 10 \\
\hline Citrus sinensis (L.) Osbeck & Rutaceae & Oranger & 9 \\
\hline Annona miricata L. & Annonaceae & Corossolier & 8 \\
\hline Arachis hypogaea L. & Fabaceae & Arachide & 8 \\
\hline Musa paradisiaca L. & Musaceae & Plantain & 8 \\
\hline Zea mays L. & Poaceae & Maïs & 8 \\
\hline Colocassia esculentus (L.) Schott & Araceae & Taro & 7 \\
\hline Daucus carota L. & Apiaceae & Carotte & 7 \\
\hline Elaes guinensis Jacq. & Arecaceae & Palmier à huille & 7 \\
\hline Hibiscus esculentus G. Cohen & Malvaceae & Gombo & 7 \\
\hline Ipomea batatas (L.) Lam. & Convolvulaceae & Patate & 7 \\
\hline Manihot esculenta Crantz & Euphorbiaceae & Manioc & 7 \\
\hline Nicotina tabacum $\mathrm{L}$. & Solanaceae & Tabac & 7 \\
\hline Solanum tuberosum L. & Solanaceae & Pomme de terre & 7 \\
\hline Dioscorea sp. & Dioscoreaceae & Igname & 6 \\
\hline Alstonia boonei De Wild. & Apocynaceae & Quinine de brousse & 5 \\
\hline Ocimum basilicum $\mathrm{L}$. & Lamiaceae & Basilic sauvage & 5 \\
\hline Pennisetum purpurea Mill. & Poaceae & Sissongho & 5 \\
\hline Solanum incanum L. & Solanaceae & Aubergine & 5 \\
\hline Coffea sp. & Rubiaceae & Caféier & 4 \\
\hline Citrus grandis Osbeck & Rutaceae & Pamplemousse & 4 \\
\hline Gossypium hirsutum L. & Malvaceae & Cotonnier & 4 \\
\hline Oryza sativum $\mathrm{L}$. & Poaceae & Riz & 4 \\
\hline $\begin{array}{l}\text { Ricinodendron heudolotii (Baill.) Pierre } \\
\text { ex Pax }\end{array}$ & Euphorbiaceae & Ndjansan & 4 \\
\hline Solanum lycopersicum L. & Solanaceae & Tomate & 4 \\
\hline Theobroma cacao L. & Sterculiaceae & Cacaoyer & 4 \\
\hline Cocos nucifera L. & Arecaceae & Cocotier & 3 \\
\hline Dacryodes edulis L. & Burseraceae & Safoutier & 3 \\
\hline Eucalyptus sailgna Smith. & Myrtaceae & Eucalyptus & 3 \\
\hline
\end{tabular}




\begin{tabular}{|c|c|c|c|}
\hline Phaseolus vulgaris $\mathrm{L}$. & Fabaceae & Haricot & 3 \\
\hline Xanthosoma sagittata Schott & Araceae & Macabo & 3 \\
\hline Ageratum conyzoides L. & Asteraceae & Reine des herbes & 2 \\
\hline Anacardium occidentalis Blanco & Anacardiaceae & Anarcadier & 2 \\
\hline Cucumeropsis sp. & Cucurbiaceae & Concombre & 2 \\
\hline $\begin{array}{l}\text { Guilbourtia tessmanii (Harms) J. } \\
\text { Léonard }\end{array}$ & Fabaceae & Bubinga & 2 \\
\hline Prunus domestica L. & Rosaceae & Prunier & 2 \\
\hline Raphia regalis P. Beauv. & Arecaceae & Palmier Raphia & 2 \\
\hline Serono repens Merck & Arecaceae & Ronier & 2 \\
\hline Tamarindus indica L. & Fabaceae & Tamarinier & 2 \\
\hline Vigua unguiculata (L.) Walp. & Fabaceae & Niébé & 2 \\
\hline Ziziphus ziziphus (L.) Meikle & Rhamnaceae & Jujubier & 2 \\
\hline Acacia sp. & Fabaceae & Acacia & 1 \\
\hline Acmella caulirhiza Del. & Asteraceae & Yeux de Poule & 1 \\
\hline Alstonia congoensis Hanfor & Apocynaceae & Quinquina & 1 \\
\hline Butyrospermum parkii Kotschy & Sapotaceae & Karité & 1 \\
\hline Cannabis sativa $\mathrm{L}$. & Cannabinaceae & Canabis & 1 \\
\hline Capsicum frutescens $\mathrm{L}$. & Solanaceae & Piment Annuel & 1 \\
\hline Cassia alata L. & Fabaceae & Dartier & 1 \\
\hline Cassia occidentalis L. & Fabaceae & Café Nègre & 1 \\
\hline Cucumis melo L. & Cucurbitaceae & Melon & 1 \\
\hline Cucurbita sp. & Cucurbitaceae & Courge & 1 \\
\hline Cucurbita pepo L. & Cucurbitaceae & Citrouille & 1 \\
\hline Digitaria exilis (Kippist) Stapf & Poaceae & Fonio & 1 \\
\hline Emilia coccinea Sims & Asteraceae & Oreille De Chien & 1 \\
\hline Eremomastax speciosa (Hochst). Cufod. & Acanthaceae & Rouge deux côtés & 1 \\
\hline $\begin{array}{l}\text { Erythrophleum suaveolens (Guill. \& } \\
\text { Pierre) Brenan }\end{array}$ & Fabaceae & Tali & 1 \\
\hline Euphorbia hirta L. & Euphorbiaceae & Okilbifed & 1 \\
\hline Gnetum africanum Wew. & Gnetaceae & Okok & 1 \\
\hline Hibiscus sabdariffa L. & Malvaceae & Oseille & 1 \\
\hline Imperata cylindrica (L.) P. Beauv. & Poaceae & Nlong & 1 \\
\hline $\begin{array}{l}\text { Irvingia gabonensis (Aubey Lec ex } \\
\text { O'Rocke) }\end{array}$ & Irvingiaceae & Mango & 1 \\
\hline Milicia axcelsa (Wew.) C.C. & Fabaceae & Iroko & 1 \\
\hline Morus migra L. & Moraceae & Murier & 1 \\
\hline Nephrolepis biserrata (Sw.) Schott & Filicineae & Fougère & 1 \\
\hline Parkia biglobasa A. Chev. & Fabaceae & Mimosa Pourpre & 1 \\
\hline Pheonix dactilifera $\mathrm{L}$. & Arecaceae & Dattier & 1 \\
\hline Piper guinensis Thonn \& Schum. & Solanaceae & Pistier & 1 \\
\hline $\begin{array}{l}\text { Pseudopondias microcarpa (A. Chev.) } \\
\text { Engl. }\end{array}$ & Anarcadiaceae & Nkangele & $\overline{1}$ \\
\hline Ricinus cummunis L. & Fabaceae & Padouk & 1 \\
\hline Saccharum officinarum $\mathrm{L}$. & Poaceae & Canna à Sucre & 1 \\
\hline Salvadora persica L. & Salvadoraceae & Arbre à Brosse & 1 \\
\hline Sesamum indica $\mathrm{L}$. & Pedaliaceae & Sésame & 1 \\
\hline Sorghum sp. & Scrophulariaceae & Sorgho & 1 \\
\hline Spathodea campanulata P. Beauv. & Bignoniaceae & Turpilier & 1 \\
\hline $\begin{array}{l}\text { Trichoscypha ferruginea (A. Chev.) A. } \\
\text { Chev. }\end{array}$ & Anarcadiaceae & Abut & 1 \\
\hline Triticum aestivum $\mathrm{L}$. & Poaceae & Blé & $\overline{1}$ \\
\hline Voacanga africana Stapf & Apocynaceae & Voacanga & 1 \\
\hline $\begin{array}{l}\text { Pethersianthus macrocarpus (P. Beauv.) } \\
\text { Liben }\end{array}$ & Lecythidaceae & Adale & 1 \\
\hline
\end{tabular}

Depending on the number of citations two major groups of plants emerged (Table 1): the group of plants whose number of citations was greater than or equal to 10 and the group for which the number of citations was less than 10 . The first group consisted of 17 plants, including 10 timbers (Adansonia digitata, 
Capsicum frutescens, Carica papaya, Cola acuminata, Citrus limon, Mangifera indica, Musa sapientum, Persea americana, Psidium guajava and Vernonia amygdalina) and seven herbs (Allium cepa, Aloe vera, Ananas comosus, A. sativum, Brassica oleracea, Zingiber officinalis and Cymbopogon citratus). The second group had 77 plants with 46 woody and 31 herbaceous. The timbers (56 plants) were so dominant in both groups while the herbaceous (38 plants) were in the minority.

Majority of the ethnic remedies were prepared in juice or paste form. Remedies were seldom prepared as poultice, decoction, powder, infusion or used unprocessed. Some ethnic remedies were prepared with out the use of diluents, while others were prepared with the addition of water. Other diluents used in the preparation of remedies included coffee, milk and human saliva. Water was the most frequently used diluent in the preparation of remedies. Availability could be one of the criteria used in the selection of diluents.

The majority remedies were applied on the skin while others were taken orally or administered through the eyes. Few remedy preparations were taken nasally, auricularly or applied locally in the mouth.

\section{DISCUSSION}

The high usage of medicinal plants among the ethnic groups could be an indication of their abundance as it was witnessed during visits to the study sites that areas very close to houses were well covered with home gardens and orchards. The study area remains humid for most months of the year creating a favorable condition for the growth of herbs. The common use of medicinal plants was also reported in studies carried out elsewhere in Cameroon (Betti, 2002; Guedje et al., 2008; Jiofack et al., 2010; Priso et al., 2011) and other parts of the world (Sunderland et al., 2003; Termote et al., 2010). Fabaceae, Arecaeae and Poaceae were represented by 10, 10 and 9 species respectively. These families are among the most represented Dicotyledonous families in the Flora of Cameroon.

The common use of leaf in the preparation of remedies could partly be due to the relative ease of finding this plant part. Leaves remain green and plenty for most months of the year since the area in which the ethnic groups reside receives good rainfall for about nine months in the year (Din et al., 2008). The use of leaves in the preparation of remedies is also common elsewhere (Mbetid-Bessane, 2005; Apema et al., 2010). Most remedies were prepared and used immediately after harvest. Few the ethnic remedies were reported to be dried and stored for future use. The frequent use of freshly processed remedies could indicate the availability of copious plant materials in the vicinity to be picked any time. Other studies conducted elsewhere also indicated the wider use of fresh materials (Okafor, 1980; Shankar et al., 2001; Dibong et al., 2011 a,b,c). The frequent use of fresh materials might also be an attempt not to lose volatile oils, the concentration of which could deteriorate on drying.

Most treatments were reported to be completed within one or two days; most of them taken once a day. Liquid remedies administered to humans were usually measured by tea or coffee glasses or plastic cups, or number of drops. When patients did not show any sign of recovery from their illnesses after treatment completion, they turned to a nearby modern health centers.

The majority of medicinal plants were uncultivated species, most of them weeds abundantly growing in disturbed habitats, mainly in crop fields, fallow lands and along hedgerows. High versatility of medicinal plants could also indicate higher diversity of active compounds contained by the species.

The transfer of medicinal plant knowledge among the ethnic groups is not taking place in a proper manner due to the lack of interest among the younger generation to learn and practice it, which might be attributed to the ever increasing influence of modernization. Results of studies conducted elsewhere also revealed similar findings (Shrestha and Dhillion, 2003; Balami, 2004; Apema et al., 2010). Literate people in the study area were found to have less knowledge of medicinal plants as compared to illiterate ones as the former are more likely to be exposed to modernization as also revealed by studies conducted elsewhere (Okafor, 1980; Ayuck et al., 1999; Hoare, 2007; Belem et al., 2007; Shankar et al., 2001; Apema et al., 2010).

The study revealed that most remedies were prepared and administrated at a household level, which is in agreement to findings of other works (Shankar et al., 2001; Belcher et al., 2005; Hoare, 2007; Belem et al., 2007; Apema et al., 2010). When deemed necessary, people could seek the help of knowledgeable people in their respective ethnic group with no or nominal charge.

Conclusion: This study showed that traditional medicine, mainly involving the use of medicinal plants, is playing a significant role in meeting the 
primary healthcare needs of the ethnic groups. Acceptance of traditional medicine and limited access to modern healthcare facilities could be considered as the main factors for the continuation of the practice.

The majority of medicinal plants were timbers which could be attributed to their abundance in areas very close to houses. Newly harvested plant materials are mostly used in the preparation of remedies indicating little practice by people to dry and store medicines for future uses, which is an indication of the availability of copious plant materials in the vicinity to be picked any time.

Priority should, be given to these plants to test their efficacy and their toxicity. The immediate and serious threat to the local medical practice in the study area seems to have come from the increasing influence of modernization. As there is no adequate modern healthcare service provision in the study area, loss of local medical knowledge and practice could negatively affect the healthcare system of the people. To arrest or slow down the trend, awareness on the contribution of traditional medical practice towards fulfilling the primary healthcare needs of the local people should be created among the youth.

\section{ACKNOWLEDGMENTS:}

We thank the UNESCO program Research of University of Douala for providing fund to cover expenses of the study.

\section{REFERENCES}

Apema, R., Mozouloua, R. and Madiapevo, S.N (2010). Inventaire préliminaire des fruits sauvages comestibles vendus sur les marches de Bangui. In X van der Burgt, $\mathrm{J}$ van der Maesen, J-M Onana (eds), Systématique et conservation des plantes africaines, pp 313-319.

Ayuk, I.T., Duguma B., Kengue J., Franzel, S., Mollet, M., Ticki-Manga and T., Zenkeng, P (1999). Uses, management and economic potential of Irvingia gabonensis in humid lowlands of Cameroon. Forest ecology and management 113: 1-9.

Belcher B, Ruiz-Perez M. and Achdiawan R (2005). Global patterns and trends in the use and management of Commercial NTFPs : implications for livelihoods and Conservation. World Development 33: 1435-1452.

Balami, N.P (2004). Ethnomedicinal use of plants among the newer community of pharping village of Kathmandu District, Nepal. TUJ 24(1).

Belem, B., Nacoulma, B.M.I., Gbangou, R., Kambou, S., Hansen, H.H., Gausset, Q., Lund, S., Raebild, A., Lompo, D., Ouedraogo, M., Theilade, I. and Boussim,
I.J (2007). Use of non wood forest products by local people bordering the "Parc National Kaboré Tambi", Burkina Faso. The Journal of Transdisciplinary Environmental Studies 6 (1): 21.

Betti, J.L. and Lejoly, J (2000). Les plantes indiquées comme antihelminthiques en thérapie traditionnelle dans la réserve de biosphère du Dja (Cameroun). Revue Soma 4-16.

Betti, J.L (2002). Medicinal plants sold in Yaounde markets, Cameroon. African Study Monographs 23 (3): 47-64.

Dibong, S.D., Mpondo Mpondo, E., Ngoye, A., Kwin, N.F. and Betti, J.L (2011a). Ethnobotanique et phytomédecine des plantes médicinales vendues sur les marchés de Douala, Cameroun. Journal of Applied Biosciences 37 : 2496-2407.

Dibong, S.D., Mpondo Mpondo, E., Ngoye, A. and Priso, R.J (2011b). Modalities of exploitation of medicinal plants in Douala region. American Journal of Food and Nutrition 1 (2): 67-73.

Dibong, S.D., Mpondo Mpondo, E., Ngoye, A. and Kwin, N.F (2011c). Plantes médicinales utilisées par les populations bassa de la région de Douala au Cameroun. International Journal of Biological and Chemical Sciences 5 (3) : 1105-1117.

Dibong ,S.D., Mpondo Mpondo, E., Ngoye, A. and Priso, R.J (2011d). Inventory and biodiversity of species edible wild fruits sold in the markets of Douala, Cameroon. International Journal of Applied Biology and Pharmaceutical Technology 2 (3): 303-311.

Din, N., Mpondo Mpondo, E., Dibong, S.D., Kwin, N.F. and Ngoye, A (2011). Inventory and identification of plants used in the treatment of diabetes in Douala town (Cameroon). European Journal of Medicinal Plants 1 (3): 60-73.

Hoare, A.L. 2007. The use of non timber forest products in the Congo-basin: constraints and opportunities. The rainforest foundation, UK.

Ghimire, S.K., Shrestha, A.K., Shrestha, K.K. and Jha, P.K (2000). Plant resources use and human impact around Royal Bardia National Park, Nepal. J. Nat. His. Mus. 19: 3-26.

Guedje, N.M. and Fankap, R. 2001. Utilisations traditionnelles de Garcinia lucida et Garcinia kola (Clusiaceae) au Cameroun. Syst. Geogr. PI. 71 : 747758.

Guedje, N.M (2002). La gestion des populations d'arbres comme outil pour une exploitation durable des produits forestiers non ligneux : l'exemple de Garcinia lucida (sud-Cameroun). The Tropenbos-Cameroon Programm, Kribi, and Université Libre de Bruxelles, Brussels, 2002. Tropenbos-Cameroun Series 5, xviii + 223p. 
Guedje, N.M., Lejoly, J., Nkongmeneck, B.A. and Jonkers, W.B.J (2003). Population dynamics of Garcinia lucida (Clusiaceae) in cameroonian Atlantic forests. Ecol. Manag. 177: 231-241.

Guedje, N.M., Mouamfon, M., Bigombé Logo, P., Abéga, S.C. and Lejoly, J (2008). Impact de la gestion socioéconomique et technique des forêts communautaires à l'échelle des économies familiales. Cas de Kompia et Kabilone (Est-Cameroun). In : Roulet PA, Assemaker $P$ (eds) Governance et Environnement en Afrique Centrale : le modèle participatif en question. Musée Royal de l'Afrique Centrale : Tervuren Belgique, pp 139-157.

Jiofack, T., Fokunang, C., Guedje, N.M., Kemeuze, V., Fongnzossie, E., Nkongmeneck, B.A, Mapongmetsem, P.M. and Tsabang, N (2010). Ethnobotanical uses of medicinals plants of two ethnoecological regions of Cameroon. International Journal of Medicine and Medical Sciences 2 (3): 60-70.

Priso R.J., Nnanga J.F., Etame J., Din N. and Amougou A (2011). Les produits forestiers non ligneux d'origine végétale: valeur et importance dans quelques marchés de la région du Littoral-Cameroon. Journal of Applied Biosciences 40 : 2715-2726.

Letouzey, R (1968). Etude phytogéographique du Cameroun. Ed. Paul Le chevalier, Paris, 511p.

Mbétid-Bessane, E (2005). Caractérisation du marché des huiles de Karité en Centrafrique. Tropicultura 23(3) : 141-145.

Okafor, J.C (1980). Edible indigeneous woody plants in the rural economy of the Nigerian forest zone. For. Ecol. Manage, 3: 45-65.
Saild (2003). Conservation de l'amande de "mangues sauvages" (Irvingia gabonensis). Agridoc (7): 3-6.

Shankar, U., Lama, S.D. and Bawa, K.S (2001). Ecology and economics of domestication of non timber forest products : an illustration of Broomgram in Darjeeling Himalaya. Journal of Tropical Forest Science 13(1): 171-191.

Sunderland, T.C.H., Besong, S. and Ayeni, J.S.O (2003). Distribution, utilization and sustainability of Non-Timber Forest products from Takamanda Forest reserve, Cameroon. In: Comiskey JA, Sunderland TCH (eds) The biodiversity of African Rainforest, SI/MAB Series 8, pp 155-172.

Termote, C., Bwam, M.M., Ndjango, J.B., Van Damme, P., Dheb'A.D (2010). Use and socio- economic importance of wild edible plants in tropicalrainforest around Kisangani, District Tshopo, DR Congo. In : X van der Burgt, J van der Maesen, J-M Onana(eds) Systématique et conservation des plantes africaines, pp 417-427.

Thiombiano, D.N.E., Lamien, N., Dibong, S.D. and Boussim., IJ (2010). Etat des peuplements des espèces ligneuses de soudure des communes rurales de Pobé-Mengao et de Nobéré (BurkinaFaso). Journal of Animal \& Plant Sciences 9(1): 1104-1116.

Tongo Etondè and Ekwalla Malobè (2003). Nos plantes qui soignent. Centre Culturel de Rencontre. $131 \mathrm{p}$.

Shrestha, P.M. and Dhillion S.S (2003). Medicinal plant diversity and use in the highlands of Dolakha district,Nepal. Journal of ethnopharmacology 86: 8196. 